\title{
Implementation of Policies Management in Educational Facilities and Infrastructure
}

\author{
(Case Study in Elementary Schools in Malang)
}

\author{
Rispa Ngindana*, Taufik Akbar Alfajri, Muhammad Rosyihan Hendrawan \\ Department of Public Administration, Faculty of Administrative Science \\ Universitas Brawijaya \\ Malang, Indonesia \\ *rispangindana@ub.ac.id, fajri@ub.ac.id, endralife@gmail.com
}

\begin{abstract}
The trend of the evaluation results from year to year leads to the standard of educators and infrastructure standards which have a relatively lower percentage of assessment compared to other standards. This research aims to determine the results of the implementation of educational infrastructure based on the standards stipulated in Government Regulation Number 19 of 2005 and Government Regulation Number 13 of 2015. The research design designed in this study is an ex post facto research design. The variables in the study are described based on the management of the facilities and infrastructure; Procurement, maintenance, utilization, and elimination. The unit of analysis in this study is an elementary level education unit, while the population is all public elementary schools in Malang, that spread over 5 districts. Sampling in this study was carried out by purposive sampling technique, there are 13 schools that have been accredited and spread over 2 districts. The research respondents were teachers and school principals, as policy implementers. The results of the study explained that the evaluation of the input variables indicated that $95 \%$ of the school samples had met the standards, this was indicated by the existence of learning facilities, libraries, laboratories, leadership rooms, teachers' rooms, places to play / exercise, places of worship, counseling rooms, health center rooms, student and teacher toilet, as well as other learning resources that meet the minimum standard criteria both in terms of size and feasibility.
\end{abstract}

Keywords—policy implementation, facility and Infrastructure, elementary school

\section{INTRODUCTION}

Education standardization in Indonesia has been mentioned in Law Number 20 of 2003 concerning the National Education System, Article 1 Paragraph (17) National education standards are the minimum criteria regarding the education system in all jurisdictions of the Republic of Indonesia. What matters that have been standardized in this Law are mentioned in Article 35 Paragraph (1), namely the standard of content, process, the competence of graduates, educational staff, facilities and infrastructure, management, financing, and education assessment. These national education standards must be regularly improved and maintained.

In order to ensure the achievement of these goals, the government stipulates that each education unit is obliged to meet the Standard of Facilities and Infrastructure. According to the Government Regulation of the Republic of Indonesia Number 32 of 2013 concerning Amendments to Government Regulation Number 19 of 2005 concerning National Education Standards, Article 1 Paragraph (9) states that the Standard for Facilities and Infrastructure are criteria regarding study rooms, places for sports, places of worship, libraries, laboratories, workshops, playgrounds, creative and recreational areas as well as other learning resources needed to support the learning process, including the use of information and communication technology.

The government issued Regulation of the Minister of National Education of the Republic of Indonesia Number 24 of 2007 concerning Standard of Facilities and Infrastructure for Elementary Schools, Junior High Schools, and Senior High School. Standard facilities and infrastructure for elementary schools include the land itself, buildings that include classrooms, library rooms, science laboratories, principal office, teachers' rooms, mosque, medical room, toilet, warehouses, circulation rooms and a place to play/exercise. This is reinforced by the results of a study by Gagarin et al., which shows that there is a positive and significant influence on the existence of school facilities and infrastructure on teacher performance [1].

Every Elementary School has the obligation to manage school facilities and infrastructure. This is intended to facilitate teaching and learning activities. With regard to unsupportive facilities and infrastructure, the implementation or implementation of the educational process may not run well. Therefore, Elementary Schools are required to meet the standard of facilities and infrastructure by implementing Regulation of the Minister of National Education of the Republic of Indonesia Number 24 of 2007. Until now, namely 
2020 the implementation of this policy has been running for a period of thirteen years.

According to Bafadal, educational facilities are all equipment, materials and furniture that are directly used in the educational process in schools [2]. Meanwhile, Mulyasa states that educational facilities are tools and equipment that are directly used and support the educational process, especially teaching and learning processes such as buildings, classrooms, tables and chairs, as well as learning tools and media [3]. From the opinion of Bafadal and Mulyasa, it can be concluded that educational facilities are all equipment that is directly involved and utilized in the educational process and are movable objects. From the opinion of Bafadal and Mulyasa, it can be concluded that educational facilities are all vehicles that are directly involved and utilized in the educational process and are movable objects.

Educational infrastructure is immovable goods or objects that can support or support the implementation of work unit duties and functions, for example, an office building [4]. Educational infrastructure is the main supporting device for an educational process or effort so that educational goals are achieved. Meanwhile, Sanjaya [5] education infrastructure is an indirect tool to achieve goals in education. When viewed from the point of view in a nutshell that educational facilities were provided after the educational infrastructure was available. Infrastructure existed before educational facilities were provided or used [5]. From the two expert opinions, it can be concluded that educational infrastructure existed before educational facilities were provided or used.

The Global Competitiveness Index 2017-2018 edition states that internet access in schools in Indonesia is ranked 45th out of a total of 137 countries surveyed. The condition related to internet access in this school was surveyed by the Pustekkom Team in 2012 by reporting that the common problems of education in remote, underdeveloped, and foremost areas are; 1). There is no power source, 2). No internet access, 3). There is no ICT infrastructure, 4). There are no human resources who have ICT skills, 5). Some locations have cell phone signals, although weak, some other locations have no signal at all [6]. Then between 2016-2017, the World Bank surveyed 270 rural and remote elementary schools in West Kalimantan and East Nusa Tenggara showing that on average $29 \%$ of schools are connected to the electricity network, and only $17 \%$ have internet networks. Also, the survey results show that $91 \%$ of schools have separate toilets for boys and girls, 54\% have libraries, and $39 \%$ have enough textbooks.

In general, the purpose of managing educational facilities and infrastructure is to provide professional services by striving for planning, procurement, use, and maintenance of facilities and infrastructure by needs, by funds, by use, and ready for use by users. The management of educational facilities includes the management of furniture, teaching aids, learning media, books, lighting, electricity, communication networks, and consumables used to support teaching and learning activities. Meanwhile, the management of education infrastructure includes land management, school buildings, classrooms, library rooms, laboratories, leadership rooms, teachers' rooms, places of worship, school health unit rooms, latrines, warehouses, prayer rooms which are needed to support the learning process sustainably.

\section{METHODS}

The research design designed in this study is an ex post facto research design or a non-experimental design. As Isaac and Michael argued, ex post facto research tries to determine a cause of something that has happened, therefore this research design does not have any treatment by the researcher [7].

The variables in the study were described based on four components such as: procurement, maintenance, utilization and elimination. Each component consisting of latent variables and each latent variable consisting of several manifest variables. The unit of analysis in this study is an elementary level education unit, while the population is all SDNs in Malang, namely 194 SDNs spread over 5 districts. Sampling in this study was carried out by purposive sampling technique, namely as many as 13 SDNs in 2 districts. The research respondents were teachers and school principals, as policy implementers. The main data collection techniques used a questionnaire, while interviews and document data were used as complementary techniques. Data reliability test result can be seen in Table 1 .

TABLE I. DATA RELIABILITY TEST RESUlt

\begin{tabular}{|c|c|}
\hline \multicolumn{2}{|c|}{ Reliability Statistics } \\
\hline Cronbach Alpha & N of Items \\
\hline .626 & 6 \\
\hline
\end{tabular}

It is said to be reliable if the value of Cronbach's Alpha $>\mathrm{r}$ table is 0.124 with $\mathrm{N}=250$. Likewise, Cronbach's Alpha coefficient is more than 0.124 , meaning the instrument used is reliable.

\section{RESULTS}

The government has determined that each education unit is obliged to meet the standard of facilities and infrastructure. According to the Government Regulation of the Republic of Indonesia Number 32 of 2013 concerning Amendments to Government Regulation Number 19 of 2005 concerning National Education Standards, Article 1 Paragraph (9) states that the Standard for Facilities and Infrastructure are criteria regarding study rooms, libraries, laboratories, sports places, residences, workshops, playgrounds, creative places and other learning resources needed to support the learning process, including the use of information and communication technology. This standardization aims to spur educational units in education management to improve the quality of education service delivery.

The procurement process is an operational function in the management of school facilities and infrastructure. On the basis 
of a series of activities to provide educational facilities and infrastructure in schools in accordance with the needs which are directly related to specifications, quantity, place, time, price, and accountable sources. The purpose of holding educational facilities and infrastructure in schools is to support teaching and learning activities between students and teachers so that they are able to run effectively and efficiently in accordance with predetermined goals.

Based on the survey that was conducted by the researchers, it can be found that the procurement process is proficient it can be seen in the table 2 .

TABLE II. PROCUREMENT PROCESS

\begin{tabular}{|c|c|c|c|c|c|}
\hline \multicolumn{2}{|c|}{} & Frequency & Percent & $\begin{array}{c}\text { Valid } \\
\text { Percent }\end{array}$ & $\begin{array}{c}\text { Cumulative } \\
\text { Percent }\end{array}$ \\
\hline \multirow{3}{*}{ Valid } & Not proficient & 56 & 22.4 & 22.4 & 22.4 \\
\cline { 2 - 6 } & Less proficient & 8 & 3.2 & 3.2 & 25.6 \\
\cline { 2 - 6 } & $\begin{array}{c}\text { Sufficiently } \\
\text { proficient }\end{array}$ & 60 & 24.0 & 24.0 & 49.0 \\
\cline { 2 - 6 } & Proficient & 125 & 50 & 50 & 99.6 \\
\cline { 2 - 6 } & Very proficient & 1 & .4 & .4 & 100.0 \\
\cline { 2 - 6 } & Total & 250 & 100.0 & 100.0 & \\
\hline
\end{tabular}

The purpose of maintaining educational facilities and infrastructure is to create a condition of good facilities and infrastructure, not damaged and ready to be used at any time to achieve effective and efficient educational goals. Maintenance activity is a process that has the aim of maintaining and preventing damage to an item so that it is able to maintain the condition of the item so that it remains good and fit for use. Maintenance includes efforts made by schools in activities aimed at maintaining technical conditions, usability, and usability of facilities and infrastructure by carrying out rehabilitation and improvements so that the mix can last longer in use.

Maintenance has excellent benefits for the facilities and infrastructure in schools. Performing the maintenance of facilities and infrastructure properly, has an impact on the longevity of goods which is much more durable, which means that there is no need to procure goods for replacement in a short time. Minimizing repair costs in the event of damage

The results of the survey data analysis show that the maintenance process of facilities and infrastructure is proficient, it can be seen from the table 3 .

TABLE III. The RESUlts of THE SURVEY DATA ANALYSIS SHOW THAT THE MAINTENANCE PROCESS OF FACILITIES AND INFRASTRUCTURE

\begin{tabular}{|c|c|c|c|c|c|}
\hline Valid & Not proficient & 1 & .4 & .4 & .4 \\
\cline { 2 - 6 } & Less proficient & 8 & 3.2 & 3.2 & 3.8 \\
\cline { 2 - 6 } & $\begin{array}{c}\text { Sufficiently } \\
\text { proficient }\end{array}$ & 60 & 24.0 & 24.0 & 27.8 \\
\cline { 2 - 6 } & Proficient & 165 & 66 & 66 & 93.8 \\
\cline { 2 - 6 } & Very proficient & 16 & 6.2 & 6.2 & 100.0 \\
\cline { 2 - 6 } & Total & 250 & 100.0 & 100.0 & \\
\hline
\end{tabular}

The utilization activity of educational facilities and infrastructure is a procedure to support learning and teaching activities in class and outside the classroom with the aim of creating achievements for students. In its implementation the principal has a role in the process of assigning tasks to schedule the use of educational facilities and infrastructure to representatives of the field of facilities and infrastructure or to officers who have a relationship with educational facilities and infrastructure.

The results of the survey data analysis show that the utilization activity of educational facilities and infrastructure is proficient, it can be seen from the table 4 .

TABLE IV. THE RESUlts OF THE SURVEy DATA ANALySIS SHOW THAT THE UTILIZATION ACTIVITY OF EDUCATIONAL FACILITIES AND INFRASTRUCTURE

\begin{tabular}{|c|c|c|c|c|c|}
\hline Valid & Not proficient & 10 & 4 & 4 & 4 \\
\cline { 2 - 6 } & Less proficient & 20 & 8 & 8 & 12 \\
\cline { 2 - 6 } & $\begin{array}{c}\text { Sufficiently } \\
\text { proficient }\end{array}$ & 50 & 20 & 20 & 32 \\
\cline { 2 - 6 } & Proficient & 150 & 60 & 60 & 92 \\
\cline { 2 - 6 } & Very proficient & 20 & 8 & 8 & 100.0 \\
\cline { 2 - 6 } & Total & 250 & 100.0 & 100.0 & \\
\hline
\end{tabular}

The elimination of educational facilities and infrastructure is carried out so that unused goods are removed from the inventory list by means of being destroyed or auctioned off. Deleting facilities and infrastructure are assets that have not been used and are not utilized because they have been severely damaged or there are already better substitute goods, deletions will be made.

The results of the survey data analysis show that the elimination process of facilities and infrastructures in elementary school is sufficiently proficient, it can be seen in the table 5 .

TABLE V. THE RESUlts of THE SURVEy DATA ANALysis SHOW THAT THE ELIMINATION PROCESS OF FACILITIES AND INFRASTRUCTURES

\begin{tabular}{|c|c|c|c|c|c|}
\hline Valid & Not proficient & 20 & 8 & 8 & 8 \\
\cline { 2 - 6 } & Less proficient & 20 & 8 & 8 & 16 \\
\cline { 2 - 6 } & $\begin{array}{c}\text { Sufficiently } \\
\text { proficient }\end{array}$ & 150 & 60 & 60 & 76 \\
\cline { 2 - 6 } & Proficient & 50 & 20 & 20 & 96 \\
\cline { 2 - 6 } & Very proficient & 10 & 4 & 4 & 100.0 \\
\cline { 2 - 6 } & Total & 250 & 100.0 & 100.0 & \\
\hline
\end{tabular}

\section{DISCUSSION}

Based on the result of the survey, it is found that the implementation management of facilities and infrastructures in elementary schools in Malang, is running properly. Based in the procurement, utilization, management and elimination process of facilities and infrastructures in elementary schools in Malang, we can see that only elimination process that need more improvement. The rest is already in proficient standard. With good facilities and infrastructure is expected elementary 
schools are able to follow the development of the 4.0 era in the future.

Education has an important role in human survival in the world because education itself has important characteristics related to humans being an inseparable unit. Education is the process of changing the attitudes and behavior of a person or group to mature humans through teaching and training efforts [8]. Apart from that, it is also explained in the Law of the Republic of Indonesia Number 20 of 2003 CHAPTER I Article 1 Paragraph 1, that:

"Education is a conscious and planned effort to create an atmosphere of learning and the learning process so that students actively develop their potential to have religiousspiritual strength, self-control, personality, intelligence, noble character, and skills needed by themselves, society, the nation. and country ".

An understanding of the principles of school-based management is indispensable for education providers to realize the goals of education to the maximum and produce highachieving students. School-Based Management directs schools to be able to innovate in managing existing educational resources. These educational resources can be in the form of facilities, infrastructure, funds, and human resources. Mustari and Rahman, provide an explanation of the basic concepts of School-Based Management, namely as the alignment of resources carried out independently by schools by involving several groups that have an interest related to schools directly in the decision-making process to meet school needs to achieve goals quality of schools in national education [9]. Thus schools can manage educational resources optimally to create quality education and following National Education Standards.

The use of a concept in improving the quality of education based on School-Based Management and National Education Standards can be through the implementation of policies regulating the quality of education itself through the role of school principals and educators. Policy implementation is a settlement activity or an implementation of a public policy that has been determined or approved by the use of means to achieve policy objectives [10]. The implementation of policies on the quality of education at the school level has an important objective, namely the maintenance and improvement of quality in a sustainable manner which is carried out systematically to meet the needs of stakeholders. Another goal by making observations about the implementation of policies on education quality is for schools to be able to increase awareness that quality improvement is the responsibility of all components involved, focusing on continuous quality improvement in educational institutions.

\section{CONCLUSION}

The evaluation of the input variables indicated that $95 \%$ of the school samples had met the standards, this was indicated by the existence of learning facilities, libraries, laboratories, leadership rooms, teachers' rooms, places to play / exercise, places of worship, counseling rooms, health center rooms, student and teacher toilet, as well as other learning resources that meet the minimum standard criteria both in terms of size and feasibility.

According to the data survey analysis, it is found that the implementation management of facilities and infrastructures in elementary schools in Malang, is running properly. Based on the procurement, utilization, management, and elimination process of facilities and infrastructures in elementary schools in Malang, we can see that only the elimination process needs more improvement. The rest is already in proficient standard. The existence of facilities and infrastructure following this standard is expected to support education in facing the industrial era 4.0.

\section{REFERENCES}

[1] M.Y. Gagarin, S. Pallu, and S.T. Baharuddin, "Pengaruh Sarana dan Prasarana Sekolah Terhadap Kinerja Guru di Kabupaten Alor Nusa Tenggara Timur," E-journal Program Pascasarjana Universitas Hasanuddin, vol. 2, no.1, 2013.

[2] I. Bafadal, Manajemen Perlengkapan Sekolah: Teori dan Aplikasinya. Jakarta: Bumi Aksara, 2008

[3] E. Mulyasa, Manajemen Berbasis Sekolah. Bandung: Remaja Rosdakarya, 2004.

[4] B. Suryosubroto, Manajemen Pendidikan di Sekolah. Jakarta: Rineka Cipta, 2004.

[5] W. Sanjaya, Perencanaan dan Desain Sistem Pembelajaran. Jakarta: Kencana, 2010.

[6] Kemdikbud, Laporan Hasil Monitoring dan Evaluasi Pusat Sumber Belajar untuk Daerah Terpencil, Tertinggal, dan Terdepan, Jakarta: Pustekkom, 2012

[7] S. Isaac and W.B. Michael, Handbook in research and evaluation for education and behavioral Sciences (2nd ed.). San Diego, California 92107: EdITS Publishers, 1981.

[8] N. Aedi, Dasar-Dasar Manajemen Pendidikan. Yogyakarta: Gosyen Publishing, 2016.

[9] M. Mustari and M.T. Rahman, Manajemen Pendidikan. Jakarta: Raja Grafika Persada, 2014.

[10] T. Tachjan, Implementasi Kebijakan Publik. Bandung: AIPI Bandung, 2006. 